\title{
Processing of Nephrolepis exaltata with Glycerine to Enhance Shelf Life by Drying
}

\author{
Biswajit Karmakar $^{1}$, Suhrita Chakrabarty ${ }^{2}$, Abid Hayat ${ }^{1 *}$ and Swarnayu Bagchi $^{1}$ \\ ${ }^{1}$ Research Scholar, Department of Post Harvest Technology, Bidhan Chandra Krishi \\ Viswavidyalaya, Mohanpur, Nadia, W.B., PIN: 741252 \\ ${ }^{2}$ AICRP on Floriculture, Directorate of Research, Bidhan Chandra Krishi Viswavidyalaya, \\ Kalyani, Nadia, W.B., PIN: 741235, India \\ *Corresponding author
}

\section{A B S T R A C T}

Cut foliage production has been rapidly increased day by day and it's playing an important role in the national income throughout world. Nephrolepis exaltata, a popular foliage commonly known as Boston fern

\section{Keywords}

Foliages, Shelf-life, Processing, Glycerine, Drying

Article Info

Accepted: 05 February 2020 Available Online: 10 March 2020 normally exhibits longer vase life compared to other ferns. To ensure the availability of the greens for a longer duration a study was conducted on effect of glycerine solutions to enhance the shelf life and extend the longevity of Nephrolepis exaltata (L.). This experiment was conducted in the year 2019 with three types of glycerine solution $(10 \%, 20 \%$, and $40 \%)$ and with two methods likely full dip and uptake as treatments followed by refrigeration. Usually shelf life of Nephrolepis exaltata is 10-12 days, but result from the experiment shows that the shelf life could be enhanced by processing with glycerin (40\%) up to 87.33 days with full dip method. The next best treatment comes from $20 \%$ glycerine solution, which resulted in shelf life of 46.67 days whereas glycerine solution $10 \%$ was effective in uptake method.

\section{Introduction}

Cut foliage is one of the major components of floricultural crops that have acquired an important position in the local and foreign markets over the world (Abou El-Ghait et al., 2012). Cut foliage constitutes an important part of florist industry everywhere.
Nephrolepis exaltata (L.) is commonly known as sword fern or Boston fern. It belongs to the family Nephrolepidaceae and is native to North, Central, and South America. It is one of the most popular cut foliage. Leaves are hairy with serrated margins. Generally the foliages of Nephrolepis having deep green colour with long lasting properties are most 
commonly used by the floral industry all over the world (Pacifici et al., 2007; Reid and Jiang 2012). As a consequence, the trade of foliage indicates that India has emerged as one of the top suppliers among the developing countries and has been successful in developing a sustainable market in EU (Ladha and Gunjal, 2011).

In India, a large amount of ferns are grown in Sikkim. A primary survey made by our team revealed that the florists of Sikkim supply the green foliage to Kolkata market, or entire West Bengal and other states, throughout the year. Based on the information from the florists and various flower shop owners of Mallickghat market, Kolkata, it seemed that Boston fern not only has local demand, but bestowed with promising export potentiality also.

Owing to foliage delicacy and tenderness, these are extremely susceptible to mechanical and physical damage during and after harvest. To ensure the availability of the greens for a longer duration, refrigerated storage holds considerable significance (Nowak and Rudnicki, 1990; Bhattacharjee, 1999; Singh et al., 2001). Thus to investigate the effect of glycerine on shelf life of Nephrolepis exaltata.

\section{Materials and Methods}

Fronds of "Nephrolepis exaltata" were harvested early in the morning from experimental plots of AICRP on Floriculture, Mondouri Nadia, West Bengal and that were brought to the laboratory within 2 hours. Then removing the pinnae from the lower third of the fronds and re-cutting to obtain a uniform length of $30 \mathrm{~cm}$, It must be ensure that the basal portion of the cut twigs certainly received a uniform dipping of $4.5 \mathrm{~cm}$ under solution those are prepared previously. The experiment was carried out by placing only the stems or dipping the foliages in the glycerine solution for evaluation of keeping quality in normal room temperature and the observations were recorded at 24, 48 and 72 hours interval after that soaking the extra solution from the fronds in bloating paper and stored at a dry place.

\section{Observation recorded}

\section{Effective shelf life (days)}

Shelf life of fronds was recorded in days. It was determined by hedonic scale acceptability score. When the acceptability score fell below 2 as per hedonic scale the fronds are regarded as commercially unacceptable and up to this day of observation were considered as shelf life and vase life.

\section{Total weight gain $(\mathrm{ml})$}

The total weight gain in cut foliage was calculated by following formula,

Transpiration loss $=$

Weight of foliage spike at last day - Initial weight of same foliage spike.

\section{Relative fresh weight (RFW) (\%)}

Relative fresh weight of the foliage was determined just before the immersing of the foliage into the solution and repeated every day until the vase life of the foliage were terminated. The fresh foliage of each foliage was expressed relative to the initial weight to represent the water status of the foliage and it was calculated by following formula,

Relative fresh weight $(\%)=$

Fresh weight on nth day

Initial fresh weight $\times 100$




\section{Overall acceptability (1-5)}

The effect of different temperature on cut foliage ware examined by determining the longevity by the day's number till wilting, the general appearance of foliage quality based on scale, ranking from one to four as described by Sangwanangkul et al., (2008).

\begin{tabular}{|l|l|}
\hline Overall Acceptability & Score \\
\hline Very Bad & 1 \\
\hline Bad & 2 \\
\hline $\begin{array}{l}\text { Moderate (May be } \\
\text { good or may be bad) }\end{array}$ & 3 \\
\hline Good & 4 \\
\hline Very good & 5 \\
\hline
\end{tabular}

\section{Results and Discussion}

Effective shelf life (Days), Total weight gain (Days), Relative fresh weight (RFW) (\%), Sensory attributes (Texture, Brittleness, Retention of shape, Colour retention, Overall acceptability)

Data presented in Table: 1 revealed that effective shelf life of Boston fern varied significantly due to different concentration of glycerin. The maximum shelf life of 87.33 days was recorded in ferns dipped in $40 \%$ glycerin $\left(\mathrm{T}_{3}\right)$ followed by 46.67 days in $20 \%$ glycerin $\left(\mathrm{T}_{2}\right)$. Whereas minimum effective shelf life of 1.0 day was recorded in control $\left(T_{7}\right)$, where ferns were kept in water for 72 hours in water and afterwards taken out and kept as such. The ideal concentration of glycerine best suited for preservation varied from species to species and method of treatment. In case of Boston fern glycerine $40 \%$ was found to be most effective in dip methods whereas glycerine-10\% was effective in uptake method.

Maximum weight gain $(0.28 \mathrm{ml})$ was observed in dip methods of $10 \%$ glycerin $\left(\mathrm{T}_{1}\right)$ followed by dip methods of $20 \%$ glycerin $\left(\mathrm{T}_{2}\right.$, $0.21 \mathrm{ml})$. On the contrary, weight loss was recorded in uptake method of $40 \%$ glycerin (0.89 ml.)

As we see in Table 1 after 72 hours, highest percentage of relative fresh weight of 107.44 per cent occurred in $10 \%$ glycerin $\left(\mathrm{T}_{1}\right)$ followed by 105.69 per cent in $20 \%$ glycerin $\left(\mathrm{T}_{2}\right)$.

\section{Sensory attributes}

Significant differences among the different treatments on the sensory qualities were obtained for the fronds of Boston fern was presented in Table 2.

\section{Texture}

Texture of fronds scored best (4.50) in glycerine $40 \%\left(\mathrm{~T}_{3}\right)$ by dip method and least score of (4.00) was recorded in glycerin $10 \%$ and $20 \%\left(\mathrm{~T}_{1} \& \mathrm{~T}_{2}\right)$, whereas in uptake method highest score of 3.50 was retained in glycerine $40 \%\left(\mathrm{~T}_{6}\right)$ and least score of 1.50 was noted in control $\left(\mathrm{T}_{7}\right)$.

\section{Brittleness}

As per the observation recorded by sensory evaluation, brittleness was not observed in in glycerine-10\% (T1), glycerine -20\% (T2) and glycerine-40\%(T3) for fronds leaves, done by dip method and uptake method. However, severe brittleness was observed in control (T7) samples.

\section{Retention of shape}

Retention of shape when the foliages were treated with different treatments pronounced the significant effect on the foliage of Nephrolepis exaltata. Maximum points of 5.00 in glycerine-40\% (T3) by dip method and showed minimum points of 2.00 when 
kept under control (T7) by uptake method. Shape retention was observed in glycerine$40 \%$ (T6) by uptake method and least retention (2.00) in control (T7) by uptake method. Likewise for obtained in glycerine$40 \%$ (T3) by dip method and minimum score (2.00) in control (T7) by uptake method.

\section{Colour retention}

Retention of colour was recorded, as per Royal Horticultural Colour Chart by panel of judges. Colour of leaves gradually changes after employing of glycerinization. In fronds initially colour of leaves was RHS137A and best retention was obtained to RHS $137 \mathrm{C}$ by dip method when treated with $40 \%$ glycerine while least retention of RHS199A was observed in glycerine $40 \%$ by dip method. For leaves of Boston fern in dip method retained deeper shade RHS199A and all treatments in uptake method retained deep colour RHSN 199A and RHSN 199C respectively, however in control (T7) by uptake method, colour retention (RHS152B) differed from the others to lighter shade.

\section{Over-all acceptability}

The over-all acceptability of glycerinized foliages differed significantly with the different treatments for different foliages. In Boston fern, over-all acceptability was highest (4.83) in dip method when glycerine$40 \%$ (T3) was used for treatment and showed least (1.63) acceptable in control (T7) by uptake method.

The present study result corroborated with the findings of Nephrolepis exaltata preserving plant material with glycol is called glycerinisation. In this technique the internal moisture of plant parts is replaced with solvents like glycol to retain their original texture, shape and colour. The processed part look more natural than air dried leaves, it is less prone to shattering and mechanical damage and more natural in appearance (Leonard, 1973). Glycerine drying is the most suitable method for drying of foliage (Anonymous, 2001). Glycols are modified alcohols containing two or more hydroxyl ($\mathrm{OH})$ groups (Morrison and Boyd, 1959). Due to presence of hydroxyl groups, glycols are hydrophilic and have strong affinity for water. This enables many glycols to be used as a humectants or softening agent. Glycols have high boiling point with low viscosity and consequently evaporates at much slower rate than water at a given temperature.

Glycerine $\left(\mathrm{CH}_{2} \mathrm{OH} . \mathrm{CHOH} . \mathrm{CH}_{2} \mathrm{OH}\right)$ is a thick syrupy sweetish liquid triol soluble in water and occurs in combination with fatty acid in fats and oil. The effectiveness of treatment in the experiment may be due to glycerine, where the water molecule inside the cell was replaced by the glycerine solution by process of osmosis. Studies in plant cell showed that, turgid cell containing cell sap with certain osmotic concentration when placed in solution of higher osmotic concentration (hypertonic solution) than the cell sap; exosmosis takes place and hypertonic solution try to become isotonic. The solution inside the cell sap is then replaced by the hypertonic solution as reported by Mitra et al., (1997).

Glycerine preserves foliages by replacing the natural moisture present in leaves with a substance that reduces its form, texture and sometimes colour. About $50 \%$ of most plant fresh weight is water but brittleness is usually only the problem if water content falls below $10 \%$ percent. At high humidity, all humectants absorb a great deal of water from the atmosphere, and also so proportionally less humectant is required to keep foliage supple. At $90 \%$ Relative humidity, glycerol will have a water content of $215 \mathrm{~g}$ per $\mathrm{g}$ of glycerol. Humectants are absorbed into plant tissues either by transpiration or by immersing the cut foliage in humectants solution. 
Table.1 Effect of glycerine on post harvest life of effective shelf life, Total weight gain (g), Relative fresh weight (\%)

\begin{tabular}{|c|c|c|c|c|c|}
\hline \multirow[t]{2}{*}{ Treatments } & \multirow{2}{*}{$\begin{array}{l}\text { Effective } \\
\text { shelf life }\end{array}$} & \multirow{2}{*}{$\begin{array}{c}\text { Total } \\
\text { weight gain } \\
(\mathrm{ml})\end{array}$} & \multicolumn{3}{|c|}{ Relative fresh weight (\%) } \\
\hline & & & after $24 \mathrm{hrs}$ & after $48 \mathrm{hrs}$ & after $72 \mathrm{hrs}$ \\
\hline $\begin{array}{c}\text { T}_{1} \text {-Full dip @ } 10 \% \\
\text { glycerine }\end{array}$ & 29.33 & 0.28 & 102.87 & 106.02 & 107.44 \\
\hline $\begin{array}{c}\mathbf{T}_{2} \text {-Full dip @ } 20 \% \\
\text { glycerine }\end{array}$ & 46.67 & 0.21 & 102.50 & 104.73 & 105.69 \\
\hline $\begin{array}{c}\text { T3-Full dip @ }_{\text {glycerine }}^{40} \% \\
\text { \% }\end{array}$ & 87.33 & 0.13 & 101.08 & 102.47 & 103.13 \\
\hline $\begin{array}{c}\mathrm{T}_{4} \text {-Absorption @ } 10 \% \\
\text { glycerine }\end{array}$ & 3.33 & -0.11 & 93.97 & 94.92 & 97.44 \\
\hline $\begin{array}{c}\mathrm{T}_{5} \text {-Absorption @ } 20 \% \\
\text { glycerine }\end{array}$ & 1.67 & -0.44 & 90.01 & 88.66 & 90.03 \\
\hline $\begin{array}{c}\text { T}_{6} \text {-Absorption @ } \\
\text { glycerine }\end{array}$ & 1.67 & -0.89 & 86.06 & 82.28 & 79.75 \\
\hline $\begin{array}{l}\mathbf{T}_{7}-\text { Control (distilled } \\
\text { water) }\end{array}$ & 0.83 & -0.27 & 102.44 & 95.33 & 91.99 \\
\hline SE.m $( \pm)$ & 1.58 & 0.04 & 0.69 & 0.94 & 1.06 \\
\hline CD at $5 \%$ & 4.82 & 0.13 & 2.12 & 2.86 & 3.23 \\
\hline
\end{tabular}

Table.2 Sensory evaluation of fronds after glycerinization

\begin{tabular}{|l|c|c|c|c|c|}
\hline \multicolumn{1}{|c|}{ Treatments } & \multicolumn{5}{|c|}{ Scores 1-5 } \\
\hline & Texture & Brittleness & Shape & $\begin{array}{c}\text { Colour } \\
\text { retention }\end{array}$ & $\begin{array}{c}\text { Overall } \\
\text { acceptance }\end{array}$ \\
\hline $\mathbf{T}_{\mathbf{1}}$-Full dip @ 10 \% glycerine & 4.00 & 4.50 & 4.50 & 4.50 & 4.23 \\
\hline $\mathbf{T}_{\mathbf{2}}$-Full dip @ 20 \% glycerine & 4.00 & 4.50 & 4.75 & 4.50 & 4.30 \\
\hline $\mathbf{T}_{\mathbf{3}}$-Full dip @ 40 \% glycerine & $\mathbf{4 . 5 0}$ & $\mathbf{5 . 0 0}$ & $\mathbf{5 . 0 0}$ & $\mathbf{5 . 0 0}$ & $\mathbf{4 . 8 3}$ \\
\hline $\begin{array}{l}\mathbf{T}_{\mathbf{4}} \text {-Absorption @ 10 \% } \\
\text { glycerine }\end{array}$ & 3.00 & 2.50 & 4.00 & 3.75 & 3.40 \\
\hline $\begin{array}{l}\mathbf{T}_{\mathbf{5}} \text {-Absorption @ 20 \% } \\
\text { glycerine }\end{array}$ & 3.00 & 2.75 & 3.75 & 3.50 & 3.23 \\
\hline $\begin{array}{l}\mathbf{T}_{\mathbf{6}} \text {-Absorption @ 40 \% } \\
\text { glycerine }\end{array}$ & 3.50 & 3.00 & 3.50 & 4.00 & 3.27 \\
\hline $\mathbf{T}_{\mathbf{7}}$-Control (distilled water) & $\mathbf{1 . 5 0}$ & $\mathbf{1 . 0 0}$ & $\mathbf{2 . 0 0}$ & $\mathbf{1 . 0 0}$ & $\mathbf{1 . 6 3}$ \\
\hline
\end{tabular}




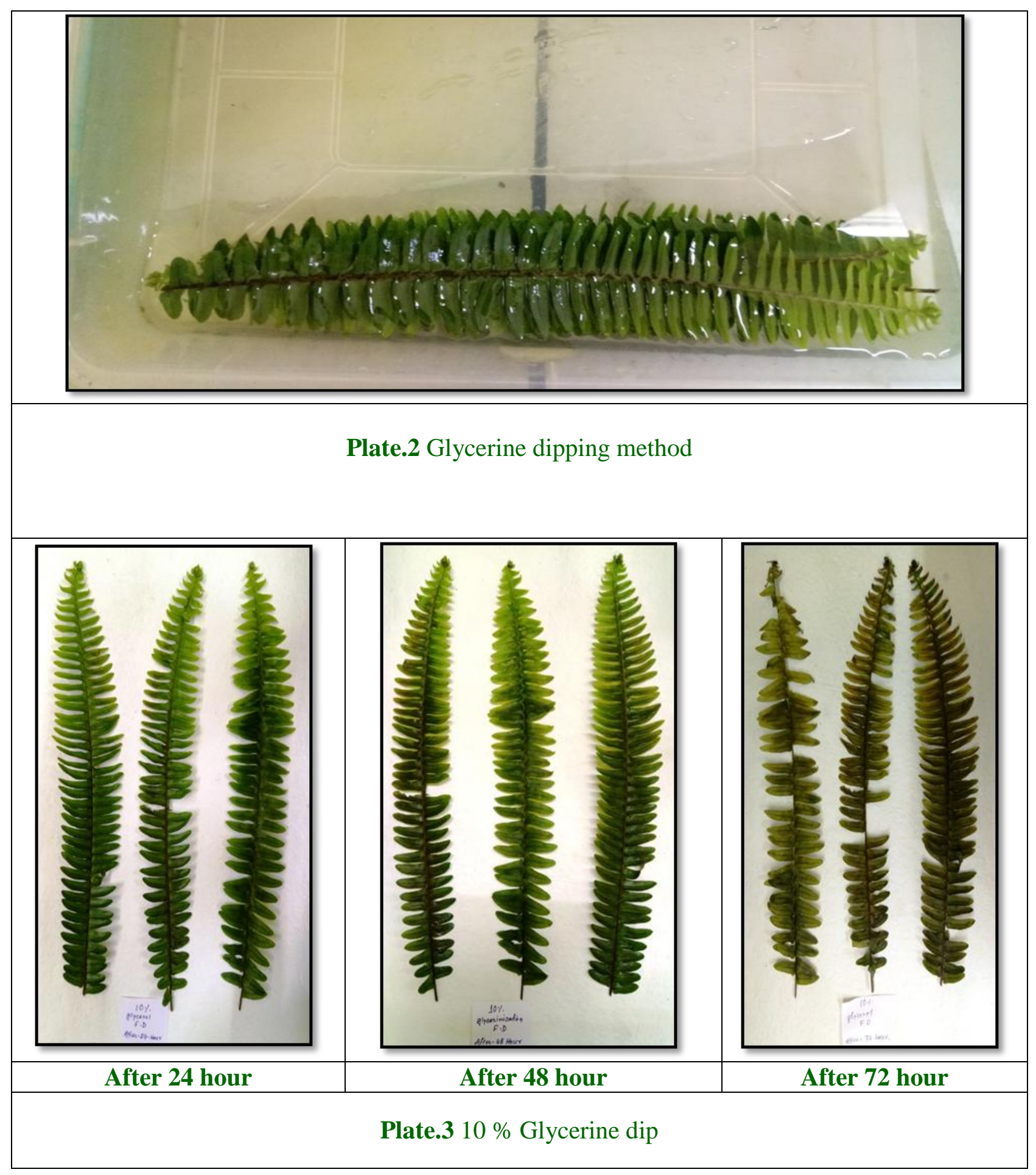




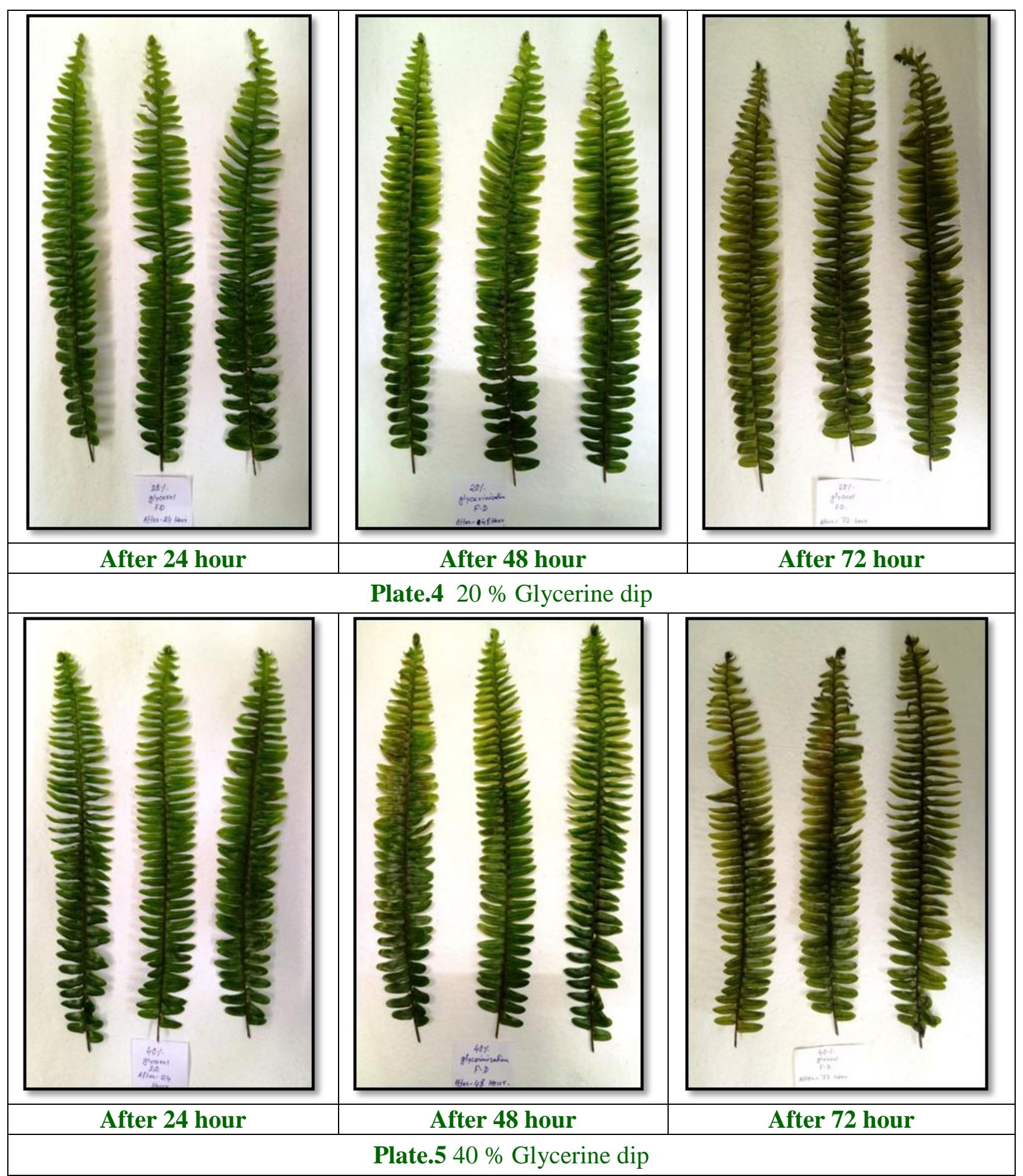


Plate.1 A-D=Showing the stages of plasmolysis; A=Normal cell ; $\mathrm{B}=$ Incipient plasmolysis ; $\mathrm{C}=$ Further shrinkage of the protoplasm and $\mathrm{D}=$ Complete plasmolysis

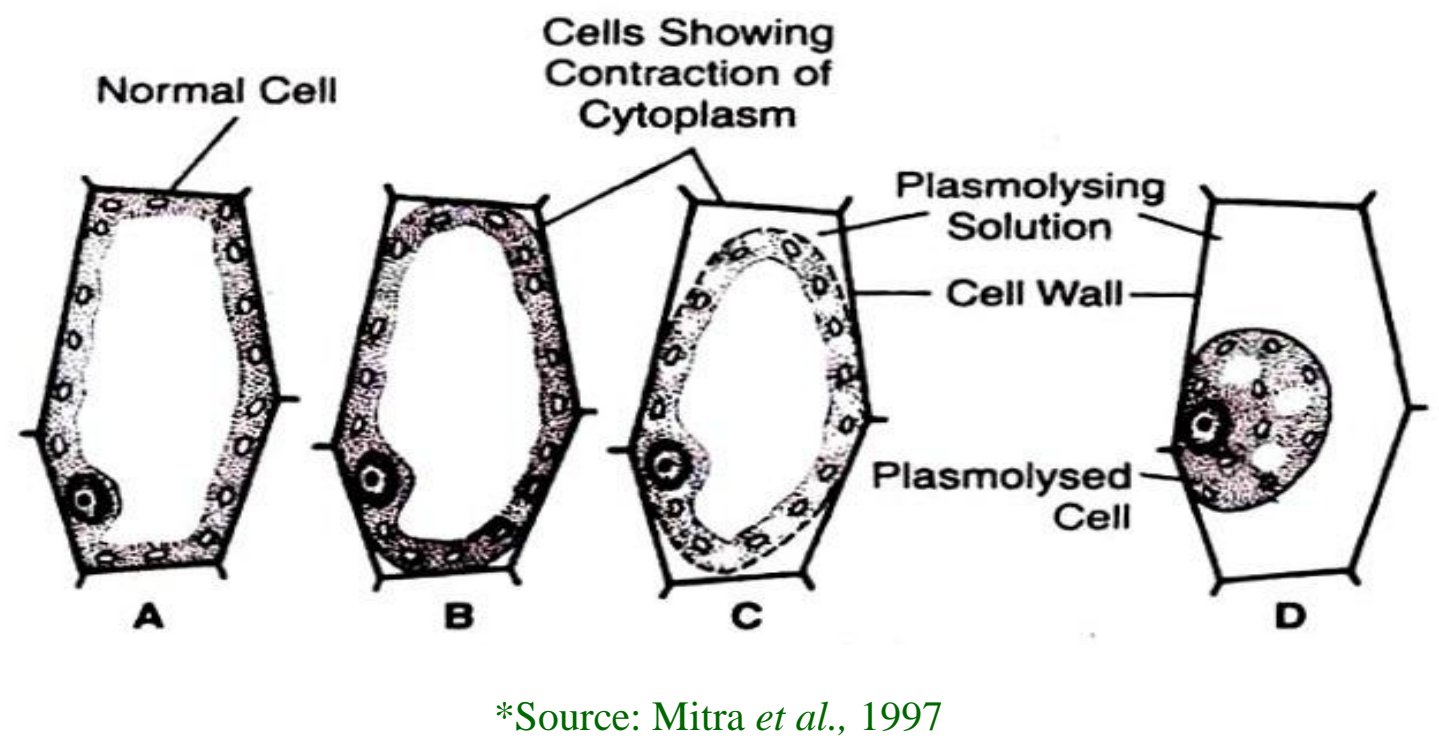

Preserving foliage in glycerine and hot water solution brings them to everlasting category. In glycerine drying the quality of flowers of product found to be good as moisture in flower is replaced by mixture of water and glycerine. It serves as a good source for microorganism so a pinch of antibiotic is needed to prevent microbial growth in the dried specimen. It replaces the water consist of leaves giving them a strong and stable nature. The preserving solution consists of one part of glycerine and two parts hot water along with the addition of chloro-hexidine to reduce bacterial growth. Most foliage preserved by glycerine turns brown but remain pliable. This technique makes the leaves and stem soft, pliable and long lasting so that they may be used over and over.

Barnett and Roger (1996) also found that preservation of foliage with glycerine will retain the shape and makes leaves soft, pliable and long lasting. Secondly Visalakshi and Jawaharlal (2014) studied effect of glycerinisation on fragile leaves and reported that the leaves treated with $30 \%$ glycol followed by $30 \%$ ethylene glycol were soft, natural in appearance with minimum moisture loss, maximum colour and shape retention. Treating foliage with glycerine yield unique results, they remain flexible, pliable, indefinitely retain natural shapes and make the dried product last longer (Conder, 1979).

Anitha (2010) reported that silver oak (Grevillea robusta) and Thuja (Thuja orientalis) were suitable plant materials for glycerine method with low brittleness and good overall acceptance. Vishnupriya (2011) studied the effect of glycerine on different plant species by treating them with different concentrations of glycerine and found that glycerine at $50 \%$ (full dip method) was best with respect to all quality parameters (shape retention, texture, colour retention, brightness, brittleness and overall acceptance).

In conclusion, the experiment was laid out in a Completely Randomized Design consisting of four glycerine concentrations i.e. control (distilled water), 10\% glycerine, $20 \%$ glycerine and $40 \%$ glycerine and two method of glycerine application i.e. uptake and full dip method and each treatment taken three 
replication for Boston fern. Usable shelf life of Nephrolepis exaltata could be enhanced by processing with glycerin $(40 \%)$ up to 87.33 days by full dip method. The next best treatment was $20 \%$ glycerine, which resulted in shelf life of 46.67 days whereas glycerine solution $10 \%$ was effective in uptake method.

\section{References}

Abou El-Ghait, E. M., A.O., Gomaa., A.S.M. Youssef., and Y.F. Mohamed., (2012). Effect of some postharvest treatments on vase life and quality of chrysanthemum (Dendranthema grandiflorum Kitam) cut flowers. Research J. Agric. and Biological Sci., 8(2): 261-271.

Anitha, M. (2010). Identification and Screening of Plant Species for Value Addition as Dry Flower Products and Standardization of Secondary Packaging Material for the Export of Pine Cones. M.Sc. Thesis. Department of Floriculture and Landscaping, Tamil Nadu Agricultural University, Coimbatore. pp. 41-43.

Anonymous. (2001). Dry flower technology. www.techno-preneur.net/information desk/.../dry flower. pdf.

Barnett, F., and Roger., 1996. New Way with Dried Flowers. Annes Publishing Ltd, London. 21p.

Bhattcharjee, S.K. (1999). Post-harvest management of cut flowers, cut foliage and post production management of potted plants. J. Ornam. Hort. 2: 32-39.

Conder, S. (1979). Commercial dried flowers. Merechurst Publication, London. pp. 60-75.

Ladha, S., and Gunjal, S. (2011).Floriculture:International Markets. In: Floriculture Today, 1-4.
Leonard. K.,1973. Dried Grasses, Grains, Gourds, Pods and Cones. The Scarecrow Press Inc., Metuchen. pp. 44-47.

Mitra, D., Guha. J., and Chowdhuri, S.K. (1997). Cells. In: Studies in botany.

Morrison, R.T., and Boyd. (1959). Organic Chemistry. Allyn and Bacon, Inc., Boston. 976p.

Nowak, J., and Rudnicki, R.M. (1990) Postharvest Handling and Storage of Cut Flower, Florist Greens and Potted Plants. Timber Press; Portland, Oregon, U.S.A. pp. 39-43.

Pacifici, S.A., Ferrante, A., Mensuali-Sodi., and Serra. G. (2007). Postharvest physiology and technology of cut Eucalyptus branches: a review. Agr.Med. 137: 124-131.

Reid, M.S. and. Jiang, C.Z. (2012). Postharvest biology and technology of cut flowers and potted plants. in: Janick, J. (Ed)., Horticulture Reviews, 14: 1-54.

Sangwanangkul, P., Saradhuldhat, P.., Paull. R.E. (2008). Survey of tropical cut flower and foliage responses to irradiation. Postharvest Biology and Technology, 48: 264-271

Singh, K., Arora, J. S., Bhattacharjee, S. K. (2001) Post harvest handling of cut flowers. Tech. Bull. No. 10, All India Co-ordinated Research project on floriculture, IARI, New Delhi, pp. 39.

Visalakshi, M., and Jawaharlal. M., 2014. Standardisation of glycerinisation technique for fragile foliages. Madras Agricultural Journal 101:401-405.

Vishnupriya K. (2011). Effect of Glycerine and Silica Gel on Drying of Plant Species for Dry Flower Product Making. M.Sc. Thesis. Department of Floriculture and Landscaping, Tamil Nadu Agriculture University, Coimbatore. pp. 36-45.

\section{How to cite this article:}

Biswajit Karmakar, Suhrita Chakrabarty, Abid Hayat and Swarnayu Bagchi. 2020. Processing of Nephrolepis exaltata with Glycerine to Enhance Shelf Life by Drying. Int.J.Curr.Microbiol.App.Sci. 9(03): 348-356. doi: https://doi.org/10.20546/ijcmas.2020.903.041 